\title{
DAILY ACTIVITY PATTERN OF THE COMMON HAMSTER (CRICETUS CRICETUS) AT TWO LOCALITIES SITUATED IN URBAN AND RURAL AREAS
}

\author{
Iwona Kaim ${ }^{1 \mathrm{~A}}$, Magdalena HędrZaK ${ }^{1 \mathrm{~B}^{*}}$, LuKAsz ZiewaCZ ${ }^{2}$ \\ ${ }^{1}$ University of Agriculture in Kraków, Department of Animal Sciences, \\ al. 29 Listopada 46, 31-425 Kraków, \\ email: A 1una_moon@interia.p1, ${ }^{B}$ rzhedrza@cyf-kr.edu.pl \\ 2 The Association of Polish Photographers of Nature \\ * corresponding author
}

\begin{abstract}
The aim of this paper is to characterize the daily activity pattern of the common hamster at two sites with different levels of human impact on environment. Locality no 1, Zesławice, is located within the administrative borders of Krakow agglomeration and is intensively penetrated by people. The farmers spend long periods of time in the fields and do much work manually. Locality no 2, Szczotkowice, is located between the villages of Szczotkowice and Pierocice, in the Działoszyce municipality. Extensive agriculture is carried out in this locality. The farmers use agricultural machines, but for most of the daytime, they are not present in the fields even during the busy harvest season. The daily activity of animals was studied using the method of food tables. The results indicate that hamsters from areas with high level of human pressures started their daily activity two hours later than those from rural areas. They exhibited higher synchronization and more uniform daily activity patterns than was recorded at the typically agricultural site. The morning and evening activity peak was significantly more distinct for urban hamsters than for rural hamsters.
\end{abstract}

Key words: urbanization, rural areas, synurbization, adaptation 


\section{INTRODUCTION}

Urban area expansion proceeds at the expense of the habitat loss of wildlife species. In some cases it is tantamount to local population extinction. Progressive urbanization and agricultural area transformation are regarded as unfavorable for common hamster occurrence (BANASZeK and ZiomeK 2010). On the other hand, reports on hamster occurrence within urban areas appear more and more frequently (BANASZEK and ZiomeK 2010, ČAnAdy 2013, Franceschini and Millesi 2001, Łopucki and Szeląg 2011, Matysek et al. 2013, Surov and TOVPINETz 2008). In most cases it is a result of the urban area extension and "absorbing" of adjacent rural areas. Then, the localities are situated on the city outskirts (ČAnady 2013, Łopucki and Szeląg 2011, Matysek et al. 2013, ZiomeK 2011). However, in some cases agricultural areas become an enclave within the city and then the sites are located within compact, built-up areas (FRANCESCHINI and Millesi 2001, Surov and Tovpinetz 2008). In both cases, the level of anthropogenic impact on the environment (i.e. human pressures) is much higher than in typical agricultural area. Life in urban areas requires many behavioral and ecological modifications in comparison to populations living outside city boundaries. LUNIAK (2004) describes the following adaptations to living in urban areas: greater tolerance to higher population density, reduced area of territories, sedentary life, ceasing seasonal migration, prolonged breeding season, greater longevity resulting from better winter survival and easier food access, prolonged circadian activity or the shift from nocturnality to diurnality, diet and feeding behavior change, greater tolerance towards people and increased intraspecific aggression.

Relatively few studies report on differences between common hamster populations from areas with diverse human pressures levels (ČANADY 2013, Niethammer 1982, Siutz and Millesi 2012, Surov and Tovpinetz 2008, Tovpinetz et al. 2006).

The aim of this paper is to characterize the daily activity pattern of the common hamster at two sites with different level of anthropogenic impact on environment.

\section{MATERIAL AND METHODS}

\section{Localities characteristics}

Research on daily activity patterns was carried out at two common hamster localities:

Site no. 1 "Zesławice" (urban hamsters), was an area with high human pressures level, situated within the borders of Krakow agglomeration (Małopolskie voivodeship),

Site no. 2 "Szczotkowice" (rural hamsters) was an area with low human pressures level, situated within the borders of Świętokrzyskie voivodeship.

Both sites are located on the Proszowice Plateau within Małopolska Upland, 30 kilometers away from each other (Fig. 1). 


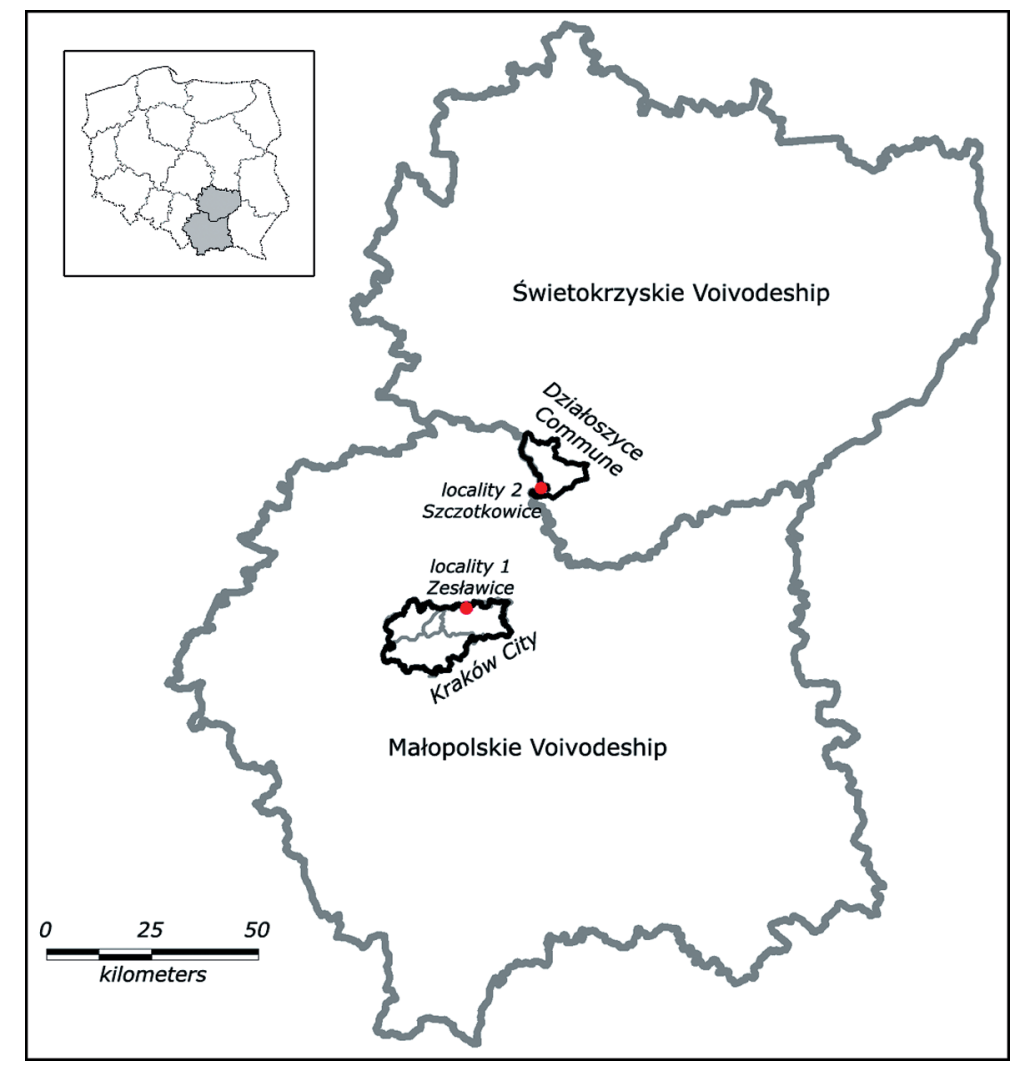

Figure 1. Location of two common hamster sites on the map of administrative borders of Małopolskie and Świętokrzyskie voivodeships in Poland.

Locality no. 1 "Zesławice" - urban site

Zesławice is a small village with typical rural character that has been annexed to the Krakow city agglomeration and is currently situated on the outskirts but within the Krakow city borders. The area belongs to Krakow's Administrative District No. XVII „Krzesławice Heights” and is situated ca. $10 \mathrm{~km}$ northeast from the city center. The site is characterized by loess soils, not much diversified terrain relief and the elevation ranges from 212 to 234 meters ASL. The village lying towards the north from the common hamster locality is called Raciborowice. From the north and the west the locality is confined by railway line. There are two reservoirs of drinkable water that occupy the area from the railway to the road that marks the southern boundary of the hamster locality. "Zeslawice" is situated In the southeastern part the active brickyard, and the area of former loam and ceramic raw materials open-cast mine is located ca. 350 meters to the south. 
Hamster occurrence was recorded in the open, arable land (Fig, 2). There are single trees and small shrubs in proximity to the site. The nearest farmsteads are ca. 20 and 50 meters away from the imaginary border of the locality. The area is intensively penetrated by walkers, and dog owners and agricultural practices during the growing season.

Locality no. 2 "Szczotkowice" - rural site

The locality is situated between the villages Szczotkowice and Pierocice. Both villages belong to Działoszyce municipality in Pińczów County. To the northeast from the hamster locality, there are the fish-breeding ponds and upon the hills there are single trees and small shrubs. Within the penetrated area, there is a single farmstead. Other buildings are situated a long distance from the site (ca. 500 meters). The terrain of the locality is undulating. Numerous hills with gentle slopes are intercepted by the narrow boggy valley in the central part. The altitude ranges from 224 to 276 meters ASL. Extensive cereal farming prevails in the area. Except during the period of the agricultural practices, the level of human disturbance is minimal.

The considerable difference in farming activity between the two localities was noticeable. At site no. 1 the work was extended during the daytime. Farmers spent long periods of time in the fields and did much work manually. Whereas, at site no. 2, human presence was very rarely recorded. Farmers used agricultural machines but they were absent for most of the day.

\section{Common hamster sites monitoring}

Field studies were conducted from April to September in 2012. The localities were characterized with regard to predators occurrence, crop structure, burrows distribution (Fig. 2), and hamsters' activity pattern.

At both sites hamster burrows were localized (Fig. 2). A single burrow was considered as a heap of soil with single or multiple tunnel openings or a single vertical tunnel opening in cases where no other openings or heaps in a radius of five meters were found. From the beginning of the hamster activity season until the period of hibernation, the dynamics of number and spatial distribution of active burrows was recorded.

Data collected in July and August, i.e. the months when rodents were the most active, were used in the present paper. During this time, observations were conducted during several time periods: Site no. 1 - July 1-6, July 18-24, August 9-13, and August 22-28; Site no. 2 - July 9-15, July 29-August 4, and August 15-19.

Observations were carried out during daylight, i.e. from 4 a.m. to 10 p.m. each day.

In order to study daily activity changes, the method of "food tables" was used. Each day of the observations, small amounts of wheat and corn as well as vegetables and fruit cut into pieces several centimeters long, big enough not to be taken by smaller rodent species, were left in the vicinity of the burrows. The tables were covered with pieces of cardboard and vegetation to protect them against birds. 
It was assumed that hamsters carry food to the burrow in a relatively short time, thus emptying the table indicating the fact that hamsters inhabiting adjacent burrows were active. In order not to accustom hamsters to a permanent feeding place, the feeding location was changed each time within each of ten fixed areas (Fig. 2). Food was displayed in two hour intervals and checked if it was taken by hamsters.

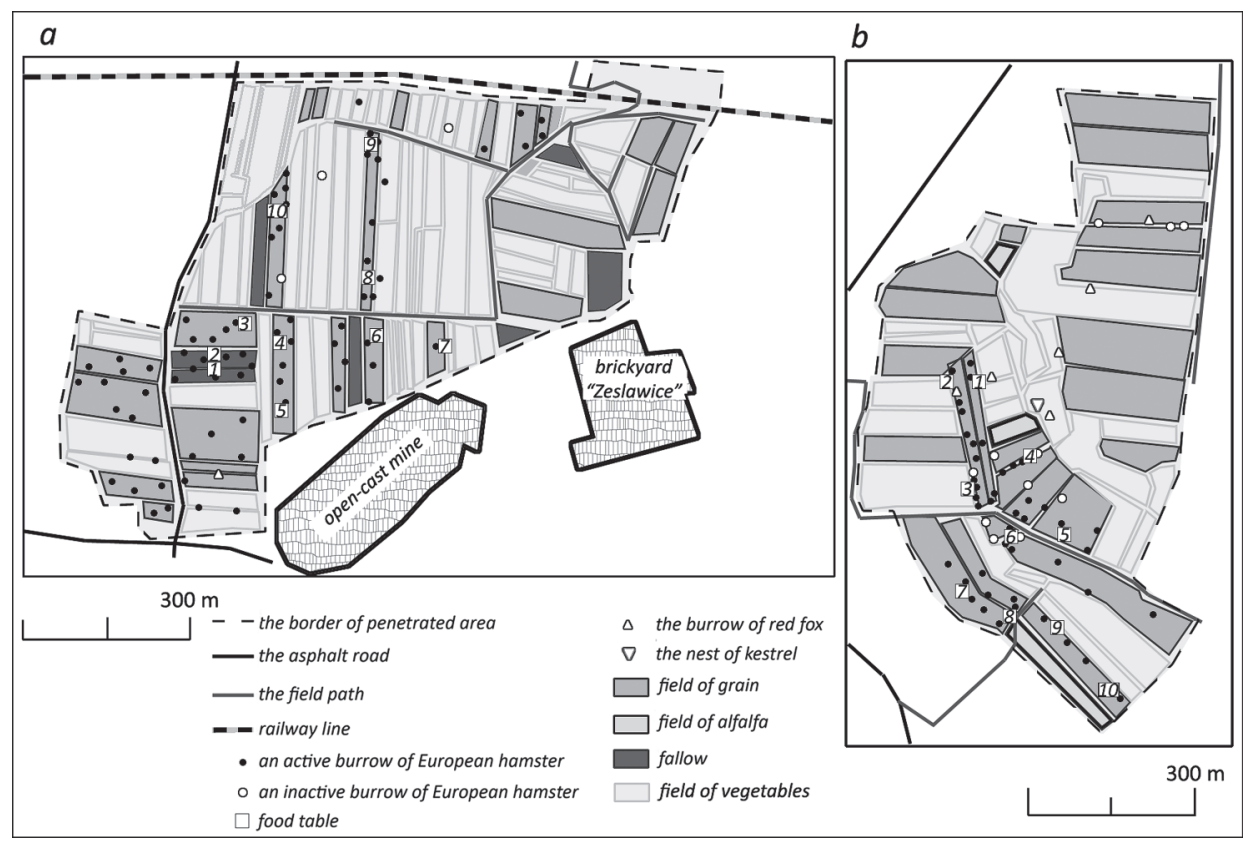

Figure 2. Maps of common hamster localities - "Zesławice" (a) and "Szczotkowice" (b) including spatial distribution of food tables.

\section{RESULTS AND DISCUSSION}

The common hamster is a species with bimodal activity pattern (GóRECKI 1977, Zıomek 2011, ZıomeK and Banaszek 2008). According to some authors, it displays dusk and nocturnal activity (GóReCKi 1977, Niethammer 1982), while others describe it as a diurnal activity species (Schmelzer 2005, Schmelzer and Millesi 2008, Ziomeк 2011). Ziomeк (2011) suggests that the hamster circadian activity pattern is modified with regard to age and gender. She claims that adult males exhibit two marked peaks in activity: from 4 a.m. to 8 a.m. and from 6 p.m. to 10 p.m. Adult females activity, at the same time, is spread over a whole day, the same is true for juveniles that left the burrows and later develop the twopeak activity model. Zıомек (2011) also reports that juveniles are more active 
in the morning, while adults exhibit higher activity in the evening. According to Niethammer (1982) nocturnal activity patterns are typical for hamsters inhabiting rural and steppe areas, whereas in the urban areas, circadian activity pattern is changed due to such factors as artificial light, different food access and a modified prey-predator relationship.

Daily activity of common hamsters in the presented study was recorded for all individuals together during July and August with the food tables method. The sex and age of hamsters are not known. At that time, density of active burrows at the "Zesławice" and "Szczotkowice" sites were 1.3 and 0.9 per hectare, respectively. Hamster activity during a particular time interval was calculated as a percentage of the cases of food being taken during this interval to the sum of all the food taking cases for this table during the whole day.

During the months when we conducted the research, there were two marked peaks of hamster activity during the day: from 4 a.m to 10 a.m. and from 4 p.m. to 10 p.m. This bimodal pattern was similar to the results of other authors (GóReCKi 1977, ZiomeK 2011, ZıомeK and BANASZeK 2008).

It was interesting that there were some differences between activities of hamsters living in the two localities. The dynamics of hamster activity from 4 a.m. to 10 p.m. at the two sites is shown in figure 3 , and statistical values calculated for both sites in particular intervals is presented in Table 1.

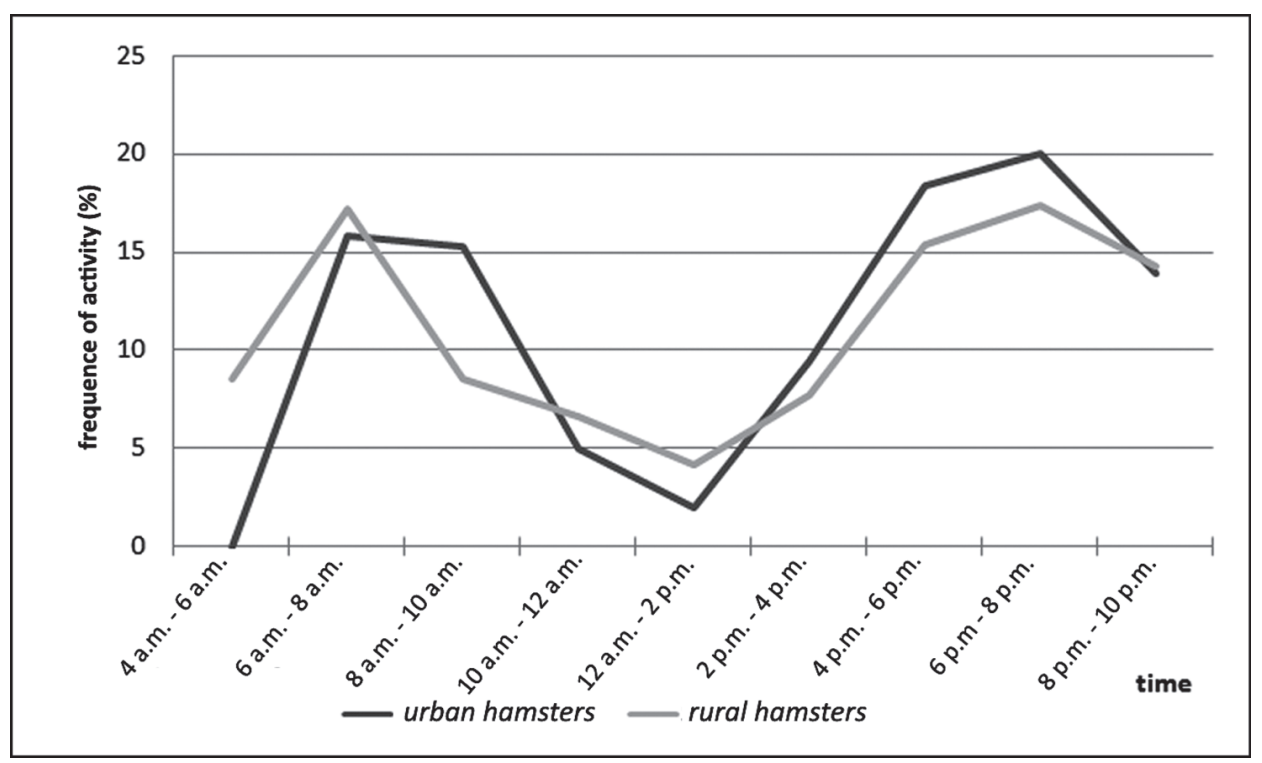

Figure 3. Common hamster daily activity dynamics in particular time intervals at the urban and rural sites. 
Table 1. Hamster activity parameters at the food tables (10 in each locality) at the urban site $\left(N_{z}=22\right.$ days $)$ and the rural site $\left(N_{S z}=18\right.$ days $)$ in particular two hour intervals from 4 a.m. to 10 p.m.

\begin{tabular}{|c|c|c|c|c|c|c|c|c|c|}
\hline $\begin{array}{c}\text { Time } \\
\text { intervals }\end{array}$ & $\begin{array}{c}4 \text { a.m. } \\
-6 \\
\text { a.m. }\end{array}$ & $\begin{array}{c}6 \text { a.m. } \\
-8 \\
\text { a.m. }\end{array}$ & $\begin{array}{c}8 \text { a.m. } \\
-10 \\
\text { a.m. }\end{array}$ & $\begin{array}{c}10 \text { a.m. } \\
-12 \\
\text { a.m. }\end{array}$ & $\begin{array}{c}12 \mathrm{a} . \mathrm{m} . \\
-2 \\
\text { p.m. }\end{array}$ & $\begin{array}{c}2 \text { p.m. } \\
-4 \\
\text { p.m. }\end{array}$ & $\begin{array}{c}\text { 4 p.m. } \\
-6 \\
\text { p.m. }\end{array}$ & $\begin{array}{c}6 \mathrm{p} . \mathrm{m} . \\
-8 \\
\text { p.m. }\end{array}$ & $\begin{array}{c}\text { 8p.m. } \\
-10 \\
\text { p.m. }\end{array}$ \\
\hline $\bar{x}_{\mathrm{z}}(\%)$ & - & 15.81 & 15.10 & 4.95 & 2.01 & 9.57 & 18.57 & 20.11 & 13.88 \\
\hline $\bar{x}_{\mathrm{Sz}}(\%)$ & 8.84 & 16.96 & 8.47 & 6.64 & 4.20 & 7.66 & 15.51 & 17.71 & 14.01 \\
\hline$S D_{\mathrm{Z}}$ & - & 1.45 & 4.31 & 1.67 & 1.25 & 3.11 & 3.15 & 1.55 & 3.96 \\
\hline$S D_{\mathrm{Sz}}$ & 3.45 & 3.79 & 2.50 & 2.12 & 3.05 & 2.63 & 3.90 & 2.49 & 4.67 \\
\hline $\min ^{-\max _{\mathrm{Z}}}$ & - & $14.1-18.1$ & $6.9-21.0$ & $1.4-7.4$ & $0.0-4.2$ & $6.1-15.3$ & $14.8-25.7$ & $17.9-22.9$ & $8.6-19.5$ \\
\hline $\begin{array}{l}\min _{-} \\
\max _{\mathrm{Sz}}\end{array}$ & $4.0-12.5$ & $11.4-23.7$ & $4.2-12.0$ & $5.1-12.0$ & $0.0-10.0$ & $2.9-11.1$ & $11.4-23.5$ & $13.6-20.8$ & $5.9-22.0$ \\
\hline$S_{Z}^{2}$ & - & 2.11 & 18.56 & 2.79 & 1.57 & 9.65 & 9.93 & 2.41 & 15.65 \\
\hline$S_{S z}^{2}$ & 11.90 & 14.35 & 6.26 & 4.51 & 9.28 & 6.93 & 15.17 & 6.22 & 21.81 \\
\hline$V_{\mathrm{Z}}$ & - & 0.09 & 0.29 & 0.34 & 0.62 & 0.32 & 0.17 & 0.08 & 0.28 \\
\hline$V_{\mathrm{Sz}}$ & 0.39 & 0.22 & 0.30 & 0.32 & 0.73 & 0.34 & 0.25 & 0.14 & 0.33 \\
\hline
\end{tabular}

Hamsters from the urban site started activity two hours later than individuals from the rural site (Fig. 3, Table 1). They never took food from 4 a.m. to 6 p.m. during the whole observation period.

The morning activity peak of hamsters from site no. 1 was from 6 to 10 a.m., whereas hamster activity at site no. 2 started two hours earlier at 4 a.m., but was the highest during the 6 to 8 a.m. interval, then decreased. In both cases, hamster activity distinctly increased from 4 to 10 p.m. However, when the activity of hamsters from both sites during peak activity hours was compared, it seemed that hamsters from the urban area were more active in the evening than in the morning hours, with a clear activity peak from 6 to 8 p.m., while the level of morning and evening activity of hamsters from the rural site was similar. It was also more evenly spread over time, i.e. the differences in the activity in three intervals from 4 to 10 p.m. were relatively low but the greatest activity value was from 6 to 8 p.m., just like at the urban site. It is hard to explain the higher evening activity of hamsters from the urban area compared to those from the rural area. During the summer, walkers are considerably more active and farmers often irrigate their crops in the evenings at site no. 1. This suggests that hamsters were not vulnerable when people were present in the vicinity of burrows. Tovpinetz et al. (2006) and Surov and Tovpinetz (2008) also reported that hamsters do not react to human and vehicle presence or to noise in the 
urban areas. Siutz and Millesi (2012) proved that juveniles from areas with high human disturbance had higher levels of cortisol, which is responsible for stress reaction, than those from low impact areas. However, cortisol level decreases with hamsters age. Thus, within the urban areas, individuals born at the beginning of the activity season have greater chances for hibernation preparation and winter survival.

Hamsters from the site located in the urban area were much more active in the interval from 8 to 10 a.m. than those from the rural site. However, considerably high values of $S D_{Z}=4.31$ and $V_{Z}=0.30$ during that time indicate that not all tables were visited equally during this interval. The activity differences between animals taking food at various tables were probably influenced by the location of the food.

Relatively low values of the mean, standard deviation and the coefficient of variation from 10 a.m. to 4 p.m. indicate that during this time, hamsters from both low and high human pressures sites exhibit low activity, however the variation in table visit frequency recorded at the rural site was higher.

Figure 4 presents daily activity charts calculated for particular food tables at both sites.

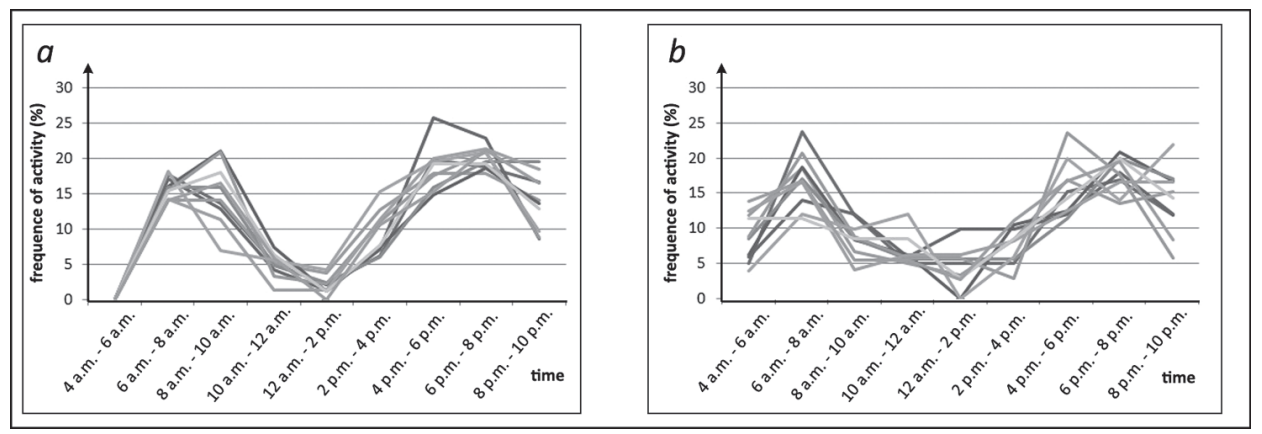

Figure 4. Hamster daily activity changes at particular food tables ( $1-10$ in each site presented in fig. 2) at "Zesławice" (a) and "Szczotkowice" (b) sites in two hour time intervals from 4 a.m. to 10 p.m.

The variation of hamster activity at particular tables at two sites is differentiated (Table 1, Fig. 4). Except the 8 to 10 a.m. and 2 to 6 p.m. intervals, the activity variation and standard deviation at particular tables was higher at the rural site than at the urban site. The difference between sites during the lowest activity hours, i.e. from 12 to 2 p.m., is noticeable. At site no. 1, virtually all tables were visited equally rarely $\left(\bar{x}_{\mathrm{z}}=2.01, S D_{\mathrm{Z}}=1.25, S_{\mathrm{Z}}{ }_{\mathrm{Z}}=1.57\right)$, which means that the activity of most hamsters decreased at that time, while at site no. 2, high variation in food taking at particular tables could be seen $\left(x_{\mathrm{Sz}}=4.20, S D_{\mathrm{Sz}}=3.05\right.$, $\left.S_{\mathrm{Sz}}^{2}=9.28\right)$. It is possibly a result of the fact that at the low human disturbance 
site, there are no factors that could influence the development of a clearly uniform daytime activity pattern for all individuals. This supposition can be confirmed by the fact that the amplitude between the highest and the lowest activity level during the daytime is higher for hamsters from the urban than from the typically rural locality. Franceschini and Millesi (2001) reported a clear twopeak daytime activity pattern in urban areas as well. Their results suggest that hamsters within cities are the most active in the early morning and in the late evening hours. The more distinct and uniform daytime activity pattern of hamsters from urban areas may be a form of adjustment to human activity rhythm or to other factors influencing activity pattern.

Hamster activity differences between the urban and the rural sites in particular time intervals are graphically presented in Figure 5, as the activity weighted averages including the variation between the cases of taking food from particular tables during an interval. The relevant statistical differences were calculated using Wilk's Lambda test $(0,7035, \mathrm{p}<0,000001)$.

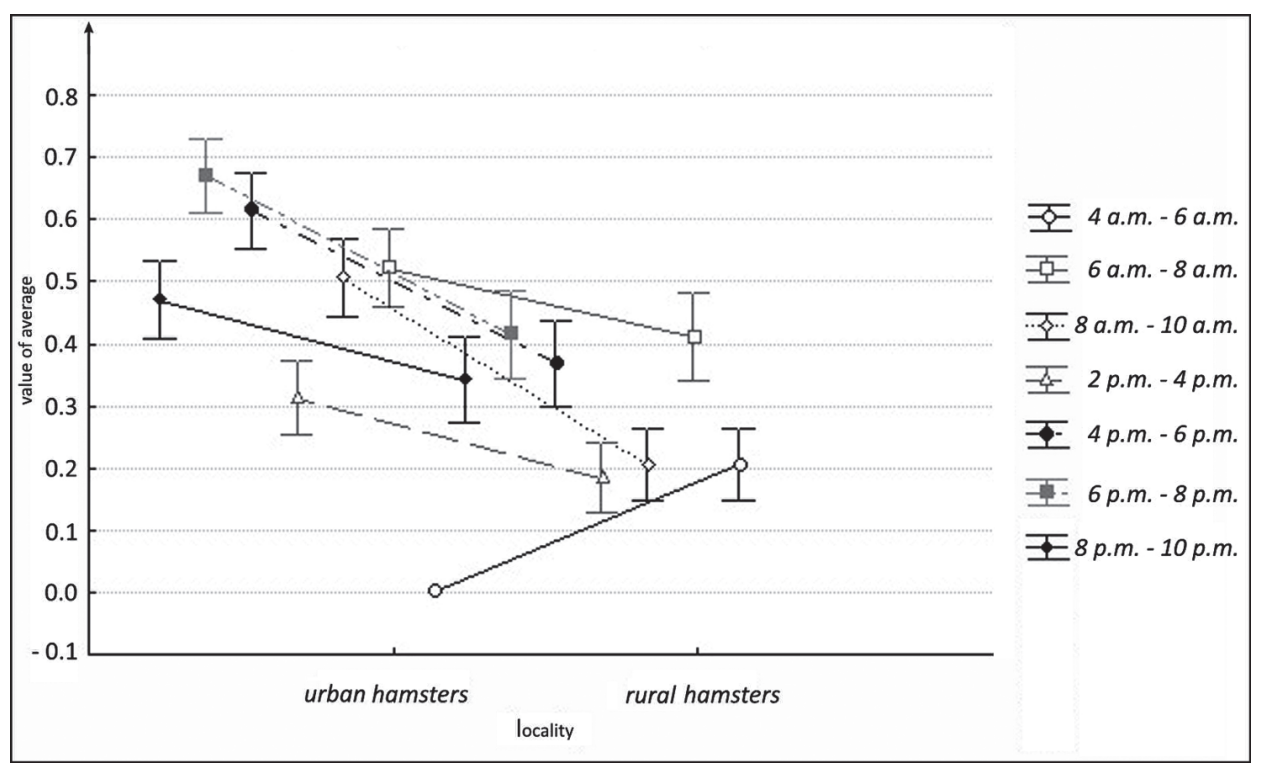

Figure 5. Hamster activity weighted averages in time intervals (in which statistical differences were relevant) at "Zesławice" and "Szczotkowice" sites including the variation between food taking cases from particular food tables during an interval.

The most apparent differences are in the intervals from 4 to 6 a.m., when hamsters from the urban area were not active and in the intervals from 8 to 10 a.m., 4 to 6 p.m. and 6 to 8 p.m. when they exhibited higher activity than hamsters from the rural site. 
Reports on common hamster populations living in urban areas from different parts of Europe suggest hamsters have low vulnerability to urbanization and adaptive capabilities. The differences in hamster daily activity rhythm in urban and rural areas can prove the fact that when the abundance and diversity of a food supply is sufficient, the species can adjust to living in urbanized areas.

However, this is mainly limited to populations occurring on the city outskirts where hamsters can find their own niche. The lack of suitable food supply, unsuitable soil structure, inability to store winter food and above all construction projects are the barriers and strict obstacles for hamsters to live in the central parts of cities (BANASzeK and Ziomek 2010, Łopucki and Szeląg 2011).

\section{DZIENNA AKTYWNOŚĆ CHOMIKA EUROPEJSKIEGO (CRICETUS CRICETUS) NA DWÓCH STANOWISKACH POŁOŻONYCH NA TERENACH O WYSOKIM I NISKIM POZIOMIE ANTROPOPRESJI}

\section{STRESZCZENIE}

Funkcjonowanie zwierząt na terenach zurbanizowanych wymusza wiele zmian w ich zachowaniu i ekologii w porównaniu z funkcjonowaniem osobników tego samego gatunku poza granicami miasta. Celem niniejszej pracy jest charakterystyka dziennej aktywności chomików europejskich na dwóch stanowiskach o zróżnicowanym poziomie antropopresji.

Badania aktywności chomików prowadzono w lipcu i sierpniu 2012 roku w godzinach 4.00-22.00 każdego dnia na dwóch stanowiskach. Stanowisko 1 Zesławice to teren o wysokim stopniu antropopresji, położony w obrębie granic miasta Krakowa. Obszar, na którym zarejestrowano obecność chomików to teren otwarty, użytkowany rolniczo. Najbliższe gospodarstwa położone są w odległości ok. 20 i $50 \mathrm{~m}$ od umownej granicy stanowiska. Teren jest intensywnie penetrowany przez osoby spacerujące, często z psami. Podczas sezonu prac rolnych, wykonywane są prace agrotechniczne, przy czym rolnicy wykonują wiele czynności ręcznie, więc długo przebywają na polach. Stanowisko 2 Szczotkowice to teren o niskim poziomie antropopresji, położony w obrębie granic woj. świętokrzyskiego. W obrębie penetrowanego obszaru, znajduje się jedno gospodarstwo domowe, natomiast pozostałe zabudowania zlokalizowane są w znacznej odległości od stanowiska (ok. $500 \mathrm{~m}$ ). Prowadzona jest tu ekstensywna gospodarka rolna, ukierunkowana głównie na uprawę zbóż. W sezonie prac polowych rolnicy szybko wykonują określony zabieg agrotechniczny z wykorzystaniem maszyn i przez większość dnia są nieobecni.

W celu określenia zmian aktywności dziennej chomików wykorzystano metodę stolików pokarmowych. Wyniki badań wskazują, że chomiki z terenów o wysokim stopniu antropopresji rozpoczynały dzienną aktywność o dwie godziny później niż chomiki z terenów rolniczych. Wykazywały też większą synchronizację i bardziej ujednolicony model aktywności w ciągu dnia, niż na stanowisku typowo rolniczym. Różnica w aktywności chomików z dwóch stanowisk polegała także na tym, że poranny i wieczorny szczyt aktywności był znacznie wyraźniejszy u chomików „miejskich” niż u osobników z terenów rolniczych. 


\section{REFERENCES}

ČANADY A. 2013: New site of the European hamster (Cricetus cricetus) in the urban environment of Košice city (Slovakia). Zoology and Ecology 23: 1, 61-65.

BanAszeK A., Ziomek J. 2010: The common hamster (Cricetus cricetus L.) population in the city of Lublin. Annales Universitatis Mariae Currie-Skłodowska Lublin - Polonia 65 (1): 59-66.

Franceschini C., Millesi E. 2001: The Common Hamster (Cricetus cricetus) in an urban environment in Vienna. Jb. Nassauisher Verein Für Naturkunde 122, 151-160.

GóreCKi A. 1977: Energy flow through the common hamster population. Acta Theriol., 22: $25-66$

LUNIAK M. 2004: Synurbization - adaptation of animal wildlife to urban development. In: Proceedings 4th International Urban Wildlife Symposium. Shaw et al., Eds. K. L. Harris, and L. van Druff, 50-55. Tucson, AZ: Univ. of Arizona.

Łopucki R., Szeląg A. 2011: Urban and suburban populations of the common hamster: differences in density and habitat preferences. In: Indykiewicz P., Jerzak L., Bohner J., Kavanagh B. (eds.) 2011: Urban fauna. Studies of animal biology, ecology, and conservation in European cities. UTP Bydgoszcz: 525-532.

Matysek M., Hędrzak M., Kuc M., Oosmólska A. 2013: The occurrence site of the common hamster Cricetus cricetus in Krakow. [In Polish with English summary] Chrońmy Przyr. Ojcz. 69 (5): 430-436.

Niethammer J. 1982: Cricetus cricetus (Linnaeus, 1758) - Hamster (Feldhamster). In: Niethammer J., Krapp F. (eds.) Handbuch der Säugetiere Europas, Bd. 2/1, Rodentia II. Akademische Verlagsgesellschaft, Wiesbaden: 7-28.

Schmelzer E. 2005: Aktivitätsmuster und Raunmutzung einer Feldhamster-population (Cricetus cricetus) im urbanen Lebensraum. Diploma Thesis. University of Vienna, Austria.

Schmelzer E., Millesi E. 2008: Activity patterns in a Population of European hamsters (Cricetus cricetus) in an urban environment. In: Proceedings of the $11^{\text {th }}$ Meeting of the International Hamsterworkgroup, vol. 2003, Budapest, Hungary: 19-22.

Siutz C., Millesi E. 2012: Effects of birth date and natal dispersal on faecal glucocorticoid concentrations in juvenile Common hamsters. General and Comparative Endocrinology 178: 323-329.

Surov A.V., Tovpinetz N. 2008: Population of Common Hamster in Simferopol (Ukraine): Fast Formation of Synanthropic Adaptations. In: HAYE M.L. (eds.) Abstract book 32: Proceedings of the $15^{\text {th }}$ Meeting of the International Hamster Workgroup, 12-14 October 2007, Kerkrade, The Netherlands: 17.

Tovpinetz M., Evstafiev I., Karaseva E. 2006: Inclination to synanthropy of the common hamster (Cricetus cricetus) based on investigations in the Crimea. The fauna in anhropogenic environment, [In Russian] Guliansk In: The Papers of Theriological School 8: 136-145.

Zıомек J. 2011: The common hamster Cricetus cricetus (L.) in the mosaic of arable fields of southern Poland. Space use, activity and behavioural patterns. [In Polish with English summary] Wydz. Biol. UAM w Poznaniu, Biologica Silesiae, Wrocław.

Ziomek J., Banaszek A. 2008: The common hamster. [In Polish with English and German summary] Wyd. Klubu Przyrodników. Świebodzin. 